\title{
MEMBINCANG PEREMPUAN BERSAMA PIERRE BOURDIEU
}

\author{
Muhammad In'am Esha \\ Dosen Fakultas Humaniora dan Budaya
}

\begin{abstract}
Abstraks
Woman issue has been an interesting topic of discussion. It is undisputable that women problem becomes celebrity at the end of $20^{\text {th }}$ century and this $21^{\text {st }}$ century. This piece of writing tries to look deeply at gender problems, one of discussions about women, in one French sociologist's perspective. From this discussion, it can be revealed that gender struggle is one of strategic steps for the struggle of social class of women. The mechanism of this sort of struggle should put habitués, arena and capital into account.
\end{abstract}

\section{A. Pendahuluan}

Perkataan perempuan seolah menjadi sesuatu yang sangat kaya. Kata ini menjadi demikian menyita perhatian segenap kalangan. Dari masa ke masa kata perempuan seolah menjadi kata 'sakti' yang telah mengharu-birukan jagad alam maya pada ini.

Cobalah tengok dalam sejarah manusia. Kata perempuan menjadi sedemikian mempesonakan. Dulu, raja-raja itu sangat bangga jika mampu "mengoleksi" ratusan perempuan untuk menjadi selirnya. Bahkan, para perempuan itu merasa bangga jika mereka dapat menjadi permaisuri atau selir Sang Raja yang dimitoskan sebagai titisan Dewa. Siapa yang tidak bangga jika diperistri oleh seorang raja? Di masa modern ini saja, di negeri ini, bahkan ada perempuan (baca: artis) yang rela diperistri oleh anaknya "raja", meskipun harus berhadapan dengan istri dan juga anaknya. Bayangkan, itu bukan 'rajanya', tetapi 'anak raja'.

Kehebatan perempuan juga tidak kecil dalam ikut membangun kohesi sosial. Tidak hanya dahulu, tetapi juga sekarang. Kita sangat beruntung memiliki Presiden Pertama yang hidup dalam masa-masa pembentukkan negara Indonesia memiliki istri yang tidak hanya berasal dari Jawa. Sehingga, ini pun mampu menjadi perekat rasa kebangsaan Indonesia dari masyarakat di mana sang perempuan itu berasal. 
Perempuan memang diciptakan serba hebat. Persis seperti kata perempuan itu sendiri. Perempuan yang berasal dari kata 'empu' itu mengandung makna sesuatu yang mengandung, memiliki, menguasai. Dari perempuanlah segalanya berasal, karena ialah yang mengandung dan melahirkan. Karena yang mengandung dan melahirkan, ialah yang berhak memiliki dan menguasai. Jika demikian, tidaklah mengherankan jika banyak yang memperebutkan perempuan. Perempuan memang sosok yang kaya dan ia adalah penguasa.

Di abad modern ini, perempuan tampil prima dalam wacana. ${ }^{1}$ Atas nama perempuan, banyak orang mendompleng ketenarannya. Persis seperti kata-kata rakyat yang selalu dikumandangkan oleh wakil rakyat kita setiap menjelang pemilu. Semua gagasan dilontarkan atas nama rakyat. Sembako untuk rakyat, janji perubahan untuk rakyat, pendidikan murah untuk rakyat, dan seterusnya. Dalam iklim demokrasi di mana rakyat adalah penguasa, maka siapa pun ingin menguasainya. Demikian pula dengan perempuan seperti yang telah saya singgung di atas.

Ketenaran dan kehebatan perempuan adalah tema yang memang layak diperbincangkan. Tulisan ini juga ingin memperbincangkan tentang persoalan perempuan. Secara khusus tulisan ini ingin membahas persoalan perempuan dalam perspektif Pierre Bourdieu. Karena yang akan kita bahas adalah Bourdieu, tentunya pertama-tama yang akan kita paparkan adalah memperkenalkan tokoh ini, baru kemudian memaparkan tentang pemikirannya tentang perempuan, dilanjutkan dengan catatan kecil sebelum kemudian diakhiri dengan penutup.

\section{B. Pierre Bourdieu: Intelektual yang Turun Gunung}

"Pierre Bourdieu, sosiolog Perancis, mempunyai latar belakang pendidikan filsafat sangat kuat. Gagasan dasarnya dikembangkan, diulangi, dan dirumuskan kembali dalam lebih dari dua puluh lima bukunya. Gagasan itu terelaborasi dalam beberapa konsep utama, yaitu habitus, ranah perjuangan, kekuasaan simbolik, dan modal budaya. Gagasan-gagasan pemikiran sosial yang

\footnotetext{
${ }^{1}$ Gerakan feminisme menjadi salah satu gerakan pemikiran dan sosial yang marak di era postmodernisme. Tidak heran jika dalam kompas 1/11/2000, Jody Williams menyebutkan bahwa persoalan perempuan menjadi isu banyak diminati. Lih. Syamsul Arifin, dkk., Spiritualisasi Islam dan Peradaban Masa Depan, Yogyakarta: SIPRESS, 1996, 196.
} 
penuh diwarnai pemberontakan ini patut diperhitungkan karena upayanya menjembatani antara teori dan tindakan. Pada awalnya Bourdieu percaya bahwa ilmu itu bebas nilai, tetapi akhirnya ia mendobrak kebuntuan moralitas bebas nilai itu untuk terlibat di dalam ranah politik." Demikianlah penjelasan Haryatmoko mengawali tulisannya tentang Bourdieu. ${ }^{2}$

Bourdieu dikenal sebagai sosiolog Perancis yang pemikiran-pemikirannya menarik diperbincangkan. Tokoh yang dilahirkan di Denguin, Pyrenia Atlantik (Perancis) tahun 1930 ini dikenal sebagai sosok yang kurang fasih dalam berbicara. Meskipun berasal dari keluarga sederhana, karena kepiawiannya, ia diterima di sekolah yang sangat prestisius, Ecole Normale Superieure yang terletak di jalan Ulm, Paris. Di kampus inilah pemikir-pemikir seperti Sartre, Levinas, Foucault, pernah melewatkan pendidikan mereka. ${ }^{3}$

Bourdieu muda menyelesaikan pendidikan di Lycee di Pau, kemudian di Lycee Louis-le-Grand (Paris), dan ke Fakultas Sastra di Paris. Bapak tiga anak ini kemudian mengajar dibeberapa tempat seperti di Fakultas Sastra di Alger (19581951), di Lille 1961-64, dan sejak tahun 1964 di Ecole des Hautes Etudes en Sciences Sociales (EHESS). Di lembaga inilah ia dipercaya menjadi direkturnya dan pemimpin pusat kajian sosiologi Eropa dan majalah Actes de la Recherche en Sciences Sociales (ARSS) di mana pada tahun 1993 lembaga risetnya mendapat medali emas dari pusat riset ilmiah nasional. Tahun 1981 diangkat sebagai pakar sosiologi di College de France. ${ }^{4}$

Tokoh yang meninggal pada 23 Januari 2002 ini kalau kita menilik tahun di mana ia menjalani kehidupannya (1960-an) adalah sosok yang mengenyak masa-masa di masa sosialisme sedang menjadi trend. Persis seperti di Indonesia di mana tahun 1960-an merupakan masa-masa sosialisme menjadi selebritis ideologi yang sarat diperbincangkan. Tidak heran jika Bourdieu juga sangat kental dengan pemikiran-pemikiran yang cenderung berseberangan dengan faham liberalisme.

${ }^{2}$ Haryatmoko,"Menyingkap Kepalsuan Budaya Penguasa", dalam Basis, Nomor 11-12, Tahun Ke52, Nov-Des 2003, 5.

${ }^{3}$ Ibid., 6.

${ }^{4}$ Ibid. 
Cermati, misalnya, tulisan yang berjudul Kritik terhadap Neoliberalisme: Utopia Eksploitasi Tanpa Batas Menjadi Kenyataan. ${ }^{5}$ Ia menuliskan bahwa 'dunia tetap ada dengan dampak-dampak neoliberalisme yang langsung bisa dilihat. Tidak hanya kesengsaraan dan penderitaan yang semakin dialami banyak orang dari masyarakat negara-negara yang secara ekonomi tergolong maju, melainkan juga peningkatan luar biasa dari kesenjangan pendapatan, makin hilangnya dunia produksi budaya yang mandiri.' Dari sini jelas bahwa Bourdieu sedemikian menaruh perhatian terhadap realitas masyarakat yang terjatuh dalam faham liberalisme. Ia mendambakan sebentuk realitas masyarakat yang intim dengan rasa solidaritas.

Tidak mengherankan jika ia membincang tentang perempuan sarat dengan kritik atas fenomena eksploitasi perempuan atas nama komoditas ekonomi yang dalam beberapa hal sangat tidak manusiawi.

Sosok Bourdieu adalah pribadi yang tidak suka hanya bergelut diranah intelektual. Ia seorang pribadi yang akrab dengan program-program pendampingan langsung di masyarakat. ${ }^{6}$ Tidak hanya fasih dalam meramu pikiran-pikirannya, tetapi juga dalam kritik sosial dengan melakukan demonstrasi. Hal inilah barangkali yang menjadikan pikiran-pikirannya terasa sangat lekat dengan fenomena sosial yang dihadapi masyarakat. Pikiran-pikiannya merupakan abstraksi aktual dan kontekstual dari fenomena yang ada.

\section{b.1 Gender, Sebuah Perbincangan Aktual}

Sebelum kita lebih lanjut membahas persoalan pandangan Bourdieu tentang perempuan. Ada baiknya dibahas terlebih dahulu persoalan gender yang merupakan wacana menarik di paroh terakhir abad ke-20 dan awal abad ke 21 ini.

Membincang perempuan memang tidak dapat dilepaskan dari persoala gender. Kata gender, menurut Nasaruddin Umar dalam bukunya Argumen

\footnotetext{
${ }^{5}$ Judul aslinya "Le neo-liberatisme, utopie (en voie de realisation) d'une exploitation sans limites" diterjemahkan oleh Haryatmoko. Lih. Pierre Bourdieu, "Kritik terhadap Neoliberalisme: Utopia Ekspoitasi tanpa Batas Menjadi Kenyataan", dalam Basis, Nomor 11-12, Tahun Ke-52, Nov-Des 2003, 25-30.

${ }^{6}$ Bourdie, seperti dijelaskan Haryatmoko, terlibat aktif dalam beberapa aksi dalam membela kelompok terpinggirkandan tertindas. Ia pernah memimpin sebuah komisi yang merefleksikan tentang isi pengajaran di sekolah yang diminta oleh Presiden Francois Mitterand. Pernah mendukung mahasiswa dan siswa SMU menentang seleksi masuk universitas dan juga ikut menandatangani petisi untuk pembangkangan sipil melawan hukum Pasqua (Menteri dalam Negeri) yang memperkeras legislasi imigrasi. Lih. Haryatmoko, Menyingkap kepalsuan. 6.
} 
Kesetaraan Gender, ${ }^{7}$ adalah suatu konsep yang digunakan untuk mengidentifikasi perbedaan laki-laki dan perempuan dilihat dari segi sosial dan budaya. Aspek yang bersifat non-biologislah yang dilihat dalam perspektif gender ini.

Perkataan gender, dengan demikian, beda dengan kata seks yang biasanya disebut dengan jenis kelamin. Seks merupakan konsep pembeda antara laki-laki dan perempuan berdasarkan realitas atau struktur biologis manusia. Bahwa antara perempuan dan laki-laki beda secara kodrat dari aspek biologisnya jelas dan tidak dapat dibantah. Perempuan memiliki bentuk kelamin yang beda dengan laki-laki. Demikian juga dengan hormon-hormon tertentu yang khas dimiliki oleh dua jenis individu ini.

Perbedaan seks inilah, tidak jarang, yang kemudian dalam realitas sosial mempengaruhi konstruksi gender. Perbedaan gender antara perempuan dan lakilaki terjadi melalui proses yang panjang. Karena adanya perbedaan-perbedaan dari sisi biologisnya antara perempuan dan laki-laki kemudian menuntut peran-peran tertentu dari dua makhluk ini yang kemudian disosialisasikan, diinternalisasikan secara turun temurun dan bahkan dengan menggunakan medan penguat dari konsep-konsep mitos dan agama. Maka, jadilah seolah-olah konstruksi gender itu menjadi sebuah kebenaran yang kodrati, tidak dapat berubah, seperti status dan keberadaan perbedanya jenis kelamin atau seks.

Siapa pun di dunia ini yang jauh sebelum masa kelahirannya dapat memilih antara menjadi makhluk Tuhan berjenis kelamin perempuan dan lakilaki? Tentu tidak ada. Seseorang yang lahir ke dunia tinggal pasrah menerima ketentuan-ketentuan jenis kelaminnya. Inilah makanya seks itu given, terberikan. Persis seperti ketidak-mampuan manusia untuk memilih di mana dan berasal dari keturuan siapa ia akan dilahirkan. Barangkali jika seks itu bisa dikonstruksi, tentu semua orang akan memilih untuk dilahirkan dari rahim perempuan yang kaya, baik, suaminya presiden, dan sebagainya.

Konstruksi gender yang seringkali dilekatkan dengan perbedaan seks yang given inilah yang seringkali menjadi salah satu mekanisme penguat dan medan

\footnotetext{
${ }^{7}$ Nasaruddin Umar, Argumen Kesetaraan Gender, Jakarta: Paramadina, 1999, 35.
} 
legitimasi. Barang kali jika tidak terjadi perubahan episteme sosial, ${ }^{8}$ mungkin tidak ada atau tidak akan muncul persoalan gender equality atau gender equity.

Kebenaran sebuah prilaku budaya dalam masyarakat erat kaitannya dengan episteme sosial yang sedang menjadi mainstream. Episteme sosial adalah sebuah kesadaran dan mekanisme sosial yang diakui dan menjadi kebenaran dalam masyarakat. Episteme sosial inilah yang mempengaruhi medan perilaku dan ukuran-ukuran kebenaran dalam suatu masyarakat dan waktu tertentu. Episteme sosial inilah yang pada kenyataannya ikut berperan dalam menentukan kebenaran-kebenaran dalam masyarakat. ${ }^{9}$

Dalam konteks Indonesia misalnya, beberapa waktu lalu episteme sosial dalam masyarakat kita sangat dipengaruhi oleh nalar reformasi. Siapapun yang ingin diakui kebenarannya atau menjadi pahlawan haruslah tidak alergi dengan kata-kata reformasi. Tidak sekedar mahasiswa, politisi pun demikian. Betapa masih lekat dalam memori kita sosok-sosok politisi yang dulu sangat "idem" dengan Orde Baru, dengan tiba-tiba mengakrabkan diri dengan reformasi. Tidak hanya politisi, reformasi ini juga mempengaruhi perilaku para pengusaha atau pelaku ekonomi. Lihat misalnya pemilik toko-toko pun harus mencantumkan kata-kata pro reformasi jika tidak ingin dikatakan sebagai "musuh".

Demikian juga dengan perbedaan gender dalam masyarakat. Mungkin tidak akan dianggap masalah jika tidak terjadi pergeseran episteme sosial. Seiring dengan perkembangan di mana hak-hak individu semakin diakui, adanya pembedaan gender itu dipandang sebagai sebuah ketidakadilan. Karena itulah muncul perjuangan di kalangan para pemikir yang untuk membela hak-hak perempuan yang dianggap tertindas oleh ketidak-adilan tersebut. ${ }^{10}$

Dalam pemikiran gender, biasanya dijelaskan bahwa terdapat lima (5) fenomena ketidakadilan terhadap perempuan (gender inequalities). Hal ini misalnya dijelaskan oleh Mansour Fakih dalam bukunya Analisis Gender dan Transformasi Sosial. ${ }^{11}$ Pertama, Marginalisasi perempuan baik di rumah tangga,

\footnotetext{
${ }^{8}$ Episteme sosial penulis dipahami sebagai konsep yang mempengaruhi moder berpikir sebuah masyarakat dalam menanggapi, merespons, dan juga menyelesaikan sebuah persoalan,. Ia bersifat abstrak dan cenderung tidak disadari, tetapi mengatur cara prilaku dan cara pandang masyarakat. ${ }^{9}$ Ibid.

${ }^{10}$ Mansour Faqih, Analisis Gender dan Transformasi Sosial, Yogyakarta: Pustaka Pelajar, 1997.

11 Ibid.
} 
tempat kerja, maupun di masyarakat, bahkan negara. Proses marginalisasi ini berakibat pada pemiskinan ekonomi perempuan. Kedua, subordinasi perempuan karena adanya anggapan gender yang salah. Seperti perempuan itu emosional sehingga tidak patut menduduki jabatan penting dalam masyarakat. Ketiga, stereotipe yang merugikan perempuan. Seperti perempuan itu pesolek untuk menarik perhatian lawan jenis. Sehingga, setiap ada kasus seksualitas yang disalahkan adalah perempuan. Keempat, bentuk-bentuk kekerasan terhadap perempuan akibat anggapan keliru dimasyarakat seperti perempuan itu lemah, sehingga leluasa di 'apa-apa' kan. Kelima, pembagian kerja yang merugikan perempuan. Seperti perempuan ditempatkan dalam ruang domestik dan bukan ruang publik. Sehingga, wawasan menjadi terbatas.

Fenomena inilah yang kemudian menjadi medan wacana bagi para pejuang-pemikir gender di masyarakat. Apa yang menjadi menjadi medan perjuangan ini muncul seiring dengan perkembangan episteme sosial yang ada di masyarakat.

\section{b.2 Praktik Sosial ala Pierre Bourdieu}

Praktik merupakan salah satu konsep utama pilihan Bourdieu di samping konsep lain habitus, arena, dan kapital. Praktik sosial dirumuskan sebagai hasil dinamika dialektika antara internalisasi eksterior dengan eksternalisasi interior. Internalisasi eksterior dimaksudkan sebagai internalisasi segala sesuatu yang dialami dan diamati dari luar diri pelaku sosial. Sedangkan eksternalisasi interior berarti pengungkapan dari segala sesuatu yang telah terinternalisasi dan menjadi bagian dari diri pelaku sosial. ${ }^{12}$

Aspek interior pelaku sosial dibentuk oleh habitus. Sedangkan aspek eksterior adalah struktur objektif yang ada di luar diri pelaku sosial. Inilah yang disebut arena. Praktik sosial merupakan dialektika antara habitus dan arena. Dengan demikian, perilaku sosial individu tidaklah bersifat otonom karena ia merupakan produk interaksi antara pelaku sosial dan struktur sosial, interaksi dialektis antara habitus dan arena atau struktur.

Menurut Bourdieu, habitus menggambarkan serangkaian kecenderungan yang mendorong dan mengarahkan manusia untuk beraksi dan bereaksi dengan

${ }^{12}$ Suma Riella Rusdiarti, "Bahasa, Pertarungan Simbolik dan Kekuasaan, dalam Basis, Nomor 11-12, Tahun Ke-52, Nov-Des 2003, 33. 
cara tertentu. Kecenderungan-kecenderungan inilah yang melahirkan praktik, persepsi, dan perilaku yang tetap, teratur, yang kemudian menjadi "mode" yang tidak dipertanyakan lagi aturan-aturan yang melatarbelakanginya. Habitus menjadi saringan, filter, dan bahkan cara pandang bagi pelaku sosial dalam memahami dunia sosial yang dihasilkan oleh struktur. Habitus inilah untuk kemudian melahirkan praktik sosial yang terus berlangsung secara terus menerus. ${ }^{13}$

Bourdieu menjelaskan bahwa dalam dunia sosial, kita mengenal medan sosial dan arena. Medan sosial mengacu pada keseluruhan konsepsi tentang dunia sosial. Konsep ini memandang bahwa realitas sosial sebagai suatu ruang (topologi). Medan sosial terdiri atas banyak arena yang saling terkait, tetapi memiliki mode sendiri. Arena adalah sebuah dunia sosial yang otonom dan bekerja dengan hukum-hukumnya sendiri. Kita misalnya mengenal arena politik, ekonomi, seni, agama dan lain sebagainya. Setiap individu yang hendak memasuki sebuah arena, perlu memahami "aturan main" di dalamnya.

Berkenaan dengan arena ini, Bourdieu menegaskan bahwa dalam setiap arena terjadi apa yang disebut dengan pertarungan dalam rangka memperebutkan dominasi. Dalam hal inilah penting kita membahas apa yang disebut dengan modal. Arena adalah bak pasar di mana semakin banyak modal yang kita miliki, kemungkinan memenangkan pertarungan dominasi menjadi sangat mungkin. Modal dimaksud dapat berupa modal ekonomi, sosial, budaya, maupun simbolik. Mereka yang tidak memiliki kapital akan terjatuh dalam dominasi.

Modal merupakan energi sosial yang hanya ada dan membuahkan hasil dalam arena pertarungan di mana ia memproduksi dan mereproduksi. Modal sosial ialah hubungan-hubungan dan jaringan hubungan-hubungan yang merupakan sumber daya yang berguna dalam penentuan dan reproduksi posisi sosial. Modal budaya dapat berupa ijazah, pengetahuan yang sudah diperoleh, kode-kode budaya, cara berbicara, kemampuan menulis, cara pembawaan, sopan santun, cara bergaul, dan sebagainya yang berperan dalam penentuandan reproduksi posisi sosial. Modal simbolik dapat berupa kantor yang luas di daerah

\footnotetext{
${ }^{13}$ Ibid., 34 .
} 
mahal atau misalnya gelar pendidikan yang dicantumkan di kartu nama, bos dan ajudannya, dan sebagainya. ${ }^{14}$

Praktik sosial, dengan demikian, tidak dapat dilepaskan dari habitus, arena, dan modal/kapital. Praktik sosial dalam kenyataanya sarat dengan perilakuperilaku bagaimana meneguhkan dominasi. Tidak heran jika kemudian Bourdieu ini tampil sebagai sosok yang melihat realitas sosial sebagai medan pertarungan individu dalam kelas-kelas sosialnya.

\section{b.3 Gender dan Perjuangan Kelas sosial}

Gerakan gender, dengan demikian, dapat dikatakan sebagai sebuah mekanisme sosial untuk memperjuangkan kelas perempuan dalam aras sosialnya. Itulah sebabnya para pemikir gender dengan sekuat tenaga dan kemampuannya untuk membongkar katub-katub sosial yang menghalangi perempuan melenggang bebas dalam aras sosial sebagaimana layaknya laki-laki.

Dalam realitasnya, pembukaan katub-katub tersebut ditempuh dengan berbagai perseptif baik teologi, sejarah, sosial, hukum, politik dan sebagainya. Kesadaran bahwa perilaku sosial tidak dapat dilepaskan dari aspek habitus, arena, dan modal, maka kinerja perjuangan gender tidak dapat dilepaskan dari tiga perspektif itu.

Perjuangan gender berusaha menciptakan habitus dalam masyarakat bahwa persepsi perempuan hanya sekedar konco wingking adalah salah. Penciptaan langkah kepada perubahan persepsi itu ditempuh dengan berbagai pendekatan baik teologis, sejarah, politik, hukum, dan sebagainya.

Dalam ranah teologis jelas sekali disebutkan bahwa pembongkaran akarakar ketidak-adilan gender dalam masyarakat sebagai akibat pemahaman yang salah akan pemaknaan kitab suci. Pemahaman terhadap kitab suci yang bias gender disebabkan oleh konstruksi sosial yang bersifat patriakhi. Memang benar bahwa al-Qur'an mempunyaikebenaran absolut dan tidak lekang oleh perjalanan waktu. Ia berlaku dari masa ke masa, shalih li kulli zaman wa makan. Akan tetapi, pemaknaaan al-Qur'an tidak dapat dilepaskan dari subjek-subjek penafsir yang sarat dan dipengaruhi oleh situasi historis dan sosial yang melingkupinya. ${ }^{15}$

\footnotetext{
${ }^{14}$ Haryatmoko, Menyingkap kepalsuan, 11-12.

${ }^{15}$ Abdul Mustaqim, "Aminah Wadud: Menuju Keadilan Gender", dalam A. Khudlori Sholeh (ed.), "Pemikiran Islam Kontemporer" Yogyakarta: Jendela, 2003, 65.
} 
Tidak heran jika tafsir yang hidup dalam suasana patriakhi akan dihasilkan model penafsiran yang bias atau setidaknya kurang berpihak kepada perempuan. Itulah sebabnya, seperti dituturkan oleh Riffat Hasan, salah seorang pemikir Islam dari India, bahwa pada saat ini perlu pembacaan ulang atas tafsir umat Islam berkenaan dengan perempuan. ${ }^{16}$

Secara ekplisit ia menjelaskan bahwa terdapat tiga asumsi teologis yang menjadi sebab mengapa perempuan termarginalisasi.

Pertama, adanya anggapan bahwa mahluk Tuhan yang unggul adalah lakilaki, karena diyakini bahwa perempuan diciptakan dari tulang rusuk laki-laki, sehingga secara ontologis perempuan adalah sekedar derivatif dan bersifat sekunder. Kedua, perempuan adalah penyebab diusirnya adam dari surga, karenanya perempuan dipandang sebagai pembawa sial, tidak ngrejekeni, dan patut dibenci. Ketiga, perempuan tidak saja diciptakan dari laki-laki namun kehadirannya memang untuk laki-laki, sehingga kehadirannya bersifat instrumental dan tidak memiliki makna yang mendasar. ${ }^{17}$

Dalam rangka menjustifikasi dan agar memiliki dasar pijakan, tidak jarang para pemikir gender memakai pendekatan historis. Mereka biasanya merujuk kembali kepada perilaku para salafus sholeh hingga perilaku profetik yang memiliki otoritas sebagai sumber tuntunan. Argumen-argumen yang dibangun bahwa perilaku Nabi saw. yang sangat memuliakan perempuan adalah sebentuk contoh bagaimana pendekatan historis ini digunakan.

Demikian juga dengan dimensi politik dan hukum. Mengingat bahwa habitus itu juga dipengaruhi oleh struktur, maka perjuangan dan bidang politik dan hukum agar memihak kepada kelas perempuan menjadi sebuah keniscayaan. Munculnya pengarusutamaan gender merupakan salah satu langkah bagaimana para pemikir mencoba mempengaruhi struktur dalam masyarakat.

Pengarusutamaan dipahami sebagai suatu strategi untuk mencapai kesetaraan dan keadilan gender melalui perencanaan dan penerapan kebijakan yang berperspektif gender pada organisasi dan institusi. Perngarusutamaan gender

\footnotetext{
${ }^{16}$ Muhammad In'am Esha, Rethingking Kalam: Sejarah Sosial Pengetahuan Islam, Mencermati Dinamika dan Aras Perkembangan Kalam Islam Kontemporer, Yogyakarta: Elsaq, 2006, 111.

${ }^{17}$ Riffat Hassan, "Isu Kesetaraan Laki-laki dan Perempuan dalam Tradisi Islam" dalam Fatimah Mernisi dan Riffat Hassan, Setara Di Hadapan Allah, Yogyakarta: LSPPA, 2000, 54.
} 
merupakan strategi alternatif untuk percepatan upaya penyadaran kesetaraan perempuan dan laki-laki yang akan menjadi landasan dalam penyusunan strategi, struktur, dan sistem dari suatu organisasi serta menjadi perilaku dan budaya dalam masyarakat. $^{18}$

Hal lain yang bisa dicermati adalah bahwa gender merupakan sebuah mekanisme bagaimana memperjuangan perempuan dalam kelas sosialnya agar terbebas dari dominasi. Pendeknya, gender merupakan medan pertarungan atau arena kaum perempuan dalam membebaskan dirinya dari struktur-struktur yang menindas dan kurang adil.

Bourdieu melihat bahwa struktur sosial yang berkembang memang sarat dengan dominasi dan sedemikian menguntungkan laki-laki. Lihat misalnya dalam hal kesuksesan sebuah produk perempuan adalah sejauhmana pemakainya mampu memikat kaum laki-laki. Seorang perempuan rela menanggung malu dan tidak mau mengungkapkan nama kekasihnya yang menghamilinya supaya nama baik dan karir si laki-laki itu tidak ternodai. ${ }^{19}$

Kalau perempuan menuntut kesetaraan gender, mereka harus mulai dengan membangun wacana baru yang mampu membongkar institusi-institusi sosial yang dibangun oleh laki-laki. Meskipun dalam realitas sosialnya dikatakan bahwa suatu institusi netral dari perspektif gender, tetapi dalam praktiknya tidak jarang laki-laki memiliki kesempatan lebih dibanding perempuan. Suatu universitas akan berpikir dua kali untuk menyekolahkan perempuan lajang karena setelah selesai sekolah ia menikah dan ikut suaminya yang bekerja di kota lain.

Bila institusi sosial didefinisikan atas dasar kepentingan dan nilai-nilai lakai-laki, dalam perkembangannya yang terjadi adalah diskualifikasi atas nasib kaum perempuan. Kondisi biologis, psikologis, dan kemampuannya dianggap tidak layak atau tidak kondusif dengan kualifikasi yang dipersyaratkan.

Selain itu, hal lain yang harus diperjuangkan dalam ranah ini adalah bagaimana kaum perempuan itu mampu memperbesar modalitas di tengah masyarakat baik dalam bentuk modal sosial, ekonomi, budaya, maupun simbolik. Pemberdayaan perempuan dalam melalui peningkatan kualitas pendidikan,

\footnotetext{
${ }^{18}$ Mansour Faqih, "Gender Mainstreaming: Strategi Mutakhir Gerakan Perempuan", dalam Gender dan Perubahan Organisasi, terj. Omi Intan N, Yogyakarta: Insist, 1999, xxxiii.

${ }^{19}$ Haryatmoko, Menyingkap Kepalsuan. 17.
} 
pemandirian ekonomi dengan memberikan lapangan kerja yang memadahi, menjadi hal yang penting.

\section{Penutup}

Dari uraian di atas dapat diambil beberapa pikiran penting bahwa membincang perempuan dan gender tidak dapat dilepaskan dari kenyataan bahwa perlu perjuangan dalam rangka merubah praktik sosial yang lebih berpihak pada kesetaraan gender.

Praktik sosial ini dapat diubah dengan cara mempengaruhi habitus individu, yang nantinya akan berpengaruh dalam ranah sosial, dengan berbagai modus seperti dengan membongkar persepsi lama tentang perempuan yang sarat diskriminasi baik dengan piranti kajian teologis, historis, politis, dan sebagainya.

Dalam rangka meneguhkan gerakan gender dalam arena pertarungan sosial, maka pemberdayaan perempuan dalam rangka membekali modalitas mereka baik modal sosial, ekonomi, simbolik, maupun budaya menjadi sebuah keniscayaan. Peningkatan daya saing perempuan melalui peningkatan kualifikasi pendidikan, pemandirian ekonomi, keterlibatan dalam ranah sosial dan politik adalah langkah-langkah yang perlu untuk senantiasa diperhatikan dan tidak biasa dipandang sebelah mata.

Sebagai kata akhir ada baiknya kita mengingat hadist nabi saw. "Yang terbaik di antara kamu adalah yang terbaik kepada keluarganya, dan aku adalah yang terbaik kepada keluargaku. Tidak menghormati kaum perempuan, kecuali orang yang terhormat, dan tidak melecehkan kaum perempuan kecuali orang yang tidak bermoral". 


\section{BIBLIOGRAFI}

Arifin, Syamsul, dkk., Spiritualisasi Islam dan Peradaban Masa Depan, Yogyakarta: SIPRESS, 1996.

Bourdieu, Pierre, "Kritik terhadap Neoliberalisme: Utopia Ekspoitasi tanpa Batas Menjadi Kenyataan", terj. Haryatmoko dalam Basis, Nomor 11-12, Tahun Ke-52, Nov-Des 2003, 25-30.

Esha, Muhammad In'am, Rethingking Kalam: Sejarah Sosial Pengetahuan Islam, Mencermati Dinamika dan Aras Perkembangan Kalam Islam Kontemporer, Yogyakarta: Elsaq, 2006.

Faqih, Mansour, "Gender Mainstreaming: Strategi Mutakhir Gerakan Perempuan", dalam Gender dan Perubahan Organisasi, terj. Omi Intan N, Yogyakarta: Insist, 1999.

--------- , Analisis Gender dan Transformasi Sosial, Yogyakarta: Pustaka Pelajar, 1999.

Haryatmoko, "Menyingkap Kepalsuan Budaya Penguasa", dalam Basis Nomor 11-12 Tahun Ke-52, November-Desember 2003.

Hassan, Riffat, "Isu Kesetaraan Laki-laki dan Perempuan dalam Tradisi Islam" dalam Fatimah Mernisi dan Riffat Hassan, Setara Di Hadapan Allah, Yogyakarta: LSPPA, 2000.

Mernisi, Fatimah dan Riffat Hasan, Setara Di Hadapan Allah, Terj. Tim LSPPA, Yogyakarta: LSPPA, 2000.

Mustaqim, Abdul, "Aminah Wadud: Menuju Keadilan Gender", dalam A. Khudlori Sholeh (ed.), "Pemikiran Islam Kontemporer" Yogyakarta: Jendela, 2003.

Rusdiarti, Suma Riella, "Bahasa, Pertarungan Simbolik dan Kekuasaan", dalam Basis Nomor 11-12 Tahun Ke-52, November-Desember 2003.

Umar, Nasaruddin, Argumen Kesetaraan Gender, Jakarta: Paramadina, 1999. 